\title{
Austria at odds with United States
}

\section{Washington}

THE Reagan Administration, which wants to control the flow of technology to the Soviet Union, has encountered problems in trying to persuade allied and neutral governments to do likewise.

Administration officials claim to have made progress in their negotiations to strengthen CoCom, the organization of NATO nations (minus Iceland and plus Japan) that approves technology exports to Eastern Bloc countries. The master list of items under CoCom's authority, they note, has been lengthened to include space launch vehicles, spacecraft and robotics.

But on other US initiatives, such as those to multiply CoCom's $\$ 0.5$ million annual budget fourfold and to add a military committee, "we have a long way to go" says one US official.

Some of the CoCom nations are arguing that they should not deprive themselves of trade with the Eastern Bloc if advanced neutral countries, such as Sweden, Switzerland, Finland and Austria, do not do likewise. So the US Administration has been engaged in delicate, secret negotiations with neutral countries in

\section{AND FURTHERMORE, NO MORE}

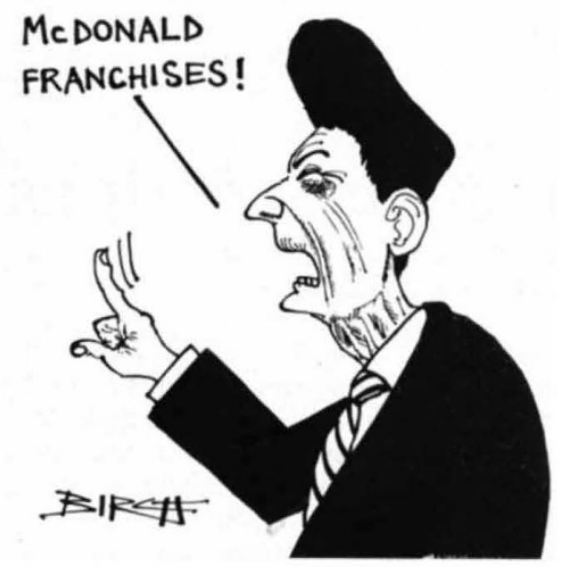

Europe and elsewhere to try to persuade them to limit their exports. Some of the neutral nations have been cooperative, but others object that such limitations would violate their neutrality.

Austria appears to have rebuffed the United States in December, after two high ranking and outspoken US defence officials, Fred C. Ikle, undersecretary of defence for policy, and Richard Perle, assistant secretary of defence for international security policy, told the Austrian press that the country should stop transferring technology to the Soviet Union and its allies. Ikle told Die Presse that Austria should erect barriers to technology transfer and that if the barriers "leak anywhere or collapse" then "we must draw the barriers closer and impose limitations". Perle made similar statements to Kronen Zeitung in November.

0028-0836/83/020104.01501.00
The publication of Ikle's remarks brought a sharp retort from Austria's Chancellor Bruno Kreisky who promptly told Kronen Zeitung that Vienna was not a "transfer centre for smuggling western technology to the Soviet Union" and that for US officials to "prescribe" what Austria exports constituted "impermissible interference in Austrian domestic affairs".

The US State Department issued a statement on the day Ikle's remarks were published, apparently trying to smooth things over. It expressed confidence that "any problems in this area involving Austria can be resolved in a manner satisfactory to both sides", and said there was no question of imposing trade sanctions on Austria.

The US Administration, in its discussions with neutral governments, argues that they could assign their state security services to ensure that technology entering the country was not smuggled out or re-exported. It is also asking them to review exports not only to the Eastern Bloc but to other countries as well, and so not violate their neutrality. It is also trying to compensate for lax enforcement policies by the Carter Administration in the late 1970s.
Says one official: "In one case we allowed the sale of a major piece of technology involving network integration of radar systems to a country on the understanding it would not be retransferred. But it was retransferred in a complete violation of the understanding. We are now trying to create a climate in which we can feel confident about allowing our technology out in the first place."

Most other governments, including those of the CoCom countries, do not review the military implications of sales of civilian equipment and technology around the world. CoCom is supposed to provide this review by examining individual applications case by case for technologies on its list. Although founded in the 1950 s to continue the post-war embargo, US officials say it has become a "rubber stamp" organization approving almost every application it receives.

The Administration has made five proposals for CoCom: updating the list, appointing a military committee, and increasing the staff and budget of CoCom's offices in Paris. It also seeks a stronger enforcement policy and harmonization of national laws on export controls.

But the CoCom governments are sceptical, one official said. "They are wondering whether the United States is really serious about this. Devorah Shapley

\section{French universities}

\section{Plans for a new reform}

M. Alain Savary, French minister of education, has come down off the fence at last. After months of vacillation, he has produced a bill reforming the universities, grandes écoles and other institutions providing higher education in France. The bill is twice as long as its predecessor, Edgar Faure's solution to the student revolution of 1968, and yet it broadly maintains the status quo: a strong division between the grandes écoles, which train an elite corps of engineers and technocrats (and to which entry is highly competitive) and the universities.

This division, some had felt, weakened the universities (and hence, indirectly, research) and Savary was strongly advised to seek a more "comprehensive" system. The grandes écoles, which are strongly represented at high levels in government and industry, fought back. The latter have now clearly won.

Even so, the Savary bill is not entirely without innovation. The appointment of university lecturers and professors will be less centralized: instead of the universities proposing a short list, and a Paris-based committee making a final selection for each post, the procedure will be reversed: Paris will make a short list and the universities will choose, thus increasing university autonomy to a small degree.

Also, universities will be "contracted" to the state for a period of years, after which a commission will assess the performance of the university and propose a new contract. And in each French départment, a small "talking-shop" will be set up across grandes écoles, universities and other institutions to help coordinate teaching policy for the first year of higher education, to the eventual benefit of the student.

Another change is one of emphasis: the universities must groom their students for useful jobs - whereas Faure insisted that the universities were not "an employment bureau".

Meanwhile, however, several more contentious issues have been relegated to the form of "decrees": strictly, details of application of the law, but ones which can be determined by the council of ministers without the approval of parliament.

There are 45 of these extra-parliamentary decrees to come, none of them yet finished - so Savary's law may yet have a sting in the tail. Among them: an important reform of the higher degree system. According to present thinking in the ministry, the "troisième cycle" will be extended into a 3-4 year PhD (the present level is slightly lower), and the "these d'Etat"' (a thesis going beyond $\mathrm{PhD}$, and necessary for a university or research post) transformed into something like an assessment of previously published papers.

Robert Walgate 